\title{
Preservation of Dodol Moyog as a Gastronomic Tourist Attraction in Cirebon Regency
}

\author{
Riadi Darwis ${ }^{1}$, Mutiara Rizky Nur Baity ${ }^{2}$ \\ ${ }^{1}$ Sekolah Tinggi Pariwisata, Bandung 40141, West Java, Indonesia \\ ${ }^{2}$ Universitas Pendidikan Indonesia, Bandung 40154, West Java Indonesia \\ *Coressponding Author.E-mail: riadidarwis@gmail.com (Riadi Darwis)
}

\begin{abstract}
Dodol moyog, a snack that has a unique name, is a traditional food originating from Cirebon Regency which is currently very rare to find, even many local people do not know the dodol moyog snack itself. This study aims to determine the gastronomic concept of dodol moyog including history, philosophy, tradition, social, and to analyze the method of cooking the traditional Cirebon regency snack, the equipment used and the manufacturing standards, and efforts to preserve dodol moyog. The research method used is a qualitative method, while the data collection technique is done by interviewing, observing, studying literature and studying documentation. The result of this research is that no one knows for sure how the history of dodol moyog is called dodol moyog because in the process of making it in "oyog-oyog" or stirred. The ingredients used to make dodol moyog are tapioca flour, brown sugar, salt and water. While the ingredients for making "mata ula" are coconut milk and sugar. Support from various parties is needed in the development of the dodol moyog business so that it can attract tourists to make dodol moyog a gastronomic tourism destination in Cirebon Regency.
\end{abstract}

Keywords: Dodol Moyog; Gastronomy; Preservation; Cirebon Regency.

\section{First Received: \\ October 2021}

Final Proof Received: December 2021

Revised:
October 2021

Accepted:

November 2021
Published:

December 2021 


\section{Introduction}

Indonesia is a country that is rich in natural beauty, traditions and culture so that it has a tourism sector that the local and foreign tourists cast no doubt on it. The tourism sector in Indonesia itself is the largest contributor of foreign exchange in Indonesia. As we know, Indonesia ranks number four in the list of worldwide countries by population with various different backgrounds such as religion, ethnicity and cultural diversity. On this basis, each region in Indonesia has its own cultural diversity in accordance with what was taught by their ancestors. This cultural diversity is reflected in the language, clothing, customs, beliefs and culinary variety of each region. Culinary variety in Indonesia has a high potential to be promoted as a tourist attraction, besides that culinary tourism is something that cannot be separated from a tourist activity to an area because food is not only a fulfillment of human physical needs but in it tucked in unique traditions and culture.

Culinary that is very diverse in Indonesia, one of which is in West Java, namely Cirebon Regency, making it an attraction for tourists who want to visit. Besides that, Cirebon Regency is used to be a place for the spread of Islam which makes it have a very abundant diversity of cultures, traditions and culinary that local and foreign tourists are eager to make a visit to just know the history of culture or are interested in enjoying the culinary that is served. In Cirebon Regency, the food offered usually has its own uniqueness, such as from its history and philosophy, taste, method of manufacture, times of serving it, method of serving, the tools used to make the food and many other unique things that become special attractions for tourists to know.

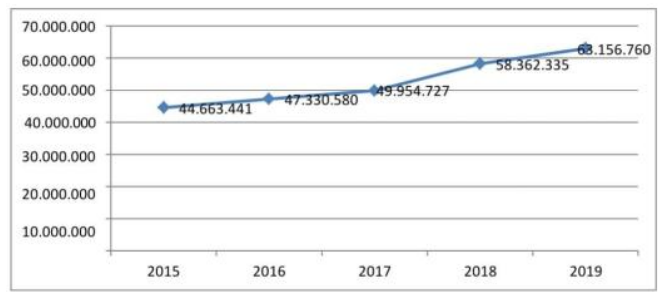

Figure 1. Graph of the Number of Domestic and International Tourists in West Java Province from 2015 to 2019

Source: Department of Tourism and Culture of West Java Province in 2019

The picture above shows that the number of domestic and foreign tourist arrivals visiting West Java from 2015 to 2019 has increased every year. The increase in the number of tourist visits is the result of the hard work of various parties including the government, the private sector, and all levels of society. Besides that, it also forms the foundation for the local government to carry out an equal distribution of tourism areas in their respective areas because West Java has a high potential to be visited by domestic and foreign tourists.

Table 1. Growth of Tourist Visits to

$\begin{array}{lcl}\text { Tourist } & \text { Attractions } & \text { in } \\ \text { Cirebon } & \text { Regency } & \text { in } \\ \text { 2016-2018 } & & \end{array}$

\begin{tabular}{|c|c|c|c|}
\hline Month & Foreign & Domestic & Total \\
\hline (1) & (2) & (3) & (4) \\
\hline January & 472 & 173.102 & 173.574 \\
\hline February & 346 & 123.810 & 124.156 \\
\hline March & 5.932 & 160.446 & 166.378 \\
\hline April & 7.210 & 191.456 & 198.666 \\
\hline May & 5.504 & 88.781 & 94.285 \\
\hline June & 6.477 & 137.331 & 143.808 \\
\hline July & 6.310 & 75.633 & 81.943 \\
\hline August & 3.952 & 55.922 & 59.874 \\
\hline September & 4.796 & 108.111 & 112.907 \\
\hline October & 6.904 & 80.963 & 87.867 \\
\hline November & 7.240 & 86.975 & 94.215 \\
\hline December & 8.271 & 97.125 & 105.396 \\
\hline 2018 & 63.414 & 1.379 .655 & 1443.069 \\
\hline 2017 & 11.910 & 701.681 & 713.591 \\
\hline 2016 & 3.759 & 635.377 & 639.136 \\
\hline
\end{tabular}

Source: https://cirebonkab.bps.go.id/ in 2018 
The Table shows that tourists have increased year by year specifically from 2016 to 2018. Seeing the increase in the number of tourists in Cirebon Regency from year to year creates a promising opportunity for the contribution of the culinary field in the Cirebon Regency tourism sector.

The potential of the gastronomic tourism sector in Cirebon Regency itself has a strong attraction for tourists who visit because of the abundant diversity of gastronomic products. Examples of well-known gastronomic products found in Cirebon Regency are tahu gejrot, empal gentong, nasi lengko, nasi jamblang, bubur sop ayam, mi koclok, empal asam, pedesan entog, sate kalong, docang, rujak kangkung, gadungan, kerupuk melarat, kue tapel, gepu, growolan, cenil, kue gapit, tape ketan and many other types of specialty foods from Cirebon Regency. However, ef among the many gastronomic products that are hunted by tourists in Cirebon Regency, there are some foods that are hard to find and the producers are rare, one of which is dodol moyog.

Dodol moyog is a snack made from tapioca flour and palm sugar and has a topping called "mata ula". Mata ula or "blondo" is made from coconut milk that is cooked for a long time until it almost forms oil. This snack has a sweet and savory taste obtained from the "mata ula". It's said to be called mata ula because it looks like a snake's eye. Dodol moyog is still cooked using firewood. This snack can be eaten anytime accompanied by hot fresh tea. Based on the information obtained, the naming of dodol moyog comes from the word "oyog-oyog" which has the meaning of being stirred. Another source says that moyog comes from the Cirebon dialect which means tired. Naming Moyog describes the process of making dodol moyog which takes a long time.
Dodol moyog is one of the traditional specialty snacks of Cirebon Regency which is hard to find and can even be said to be almost extinct at this time. In Cirebon Regency itself, many surrounding communities do not know what this dodol moyog snack looks like. In addition, many modern people today do not know that the dodol moyog snack comes from Cirebon Regency. The existence of dodol moyog producers who still survive today needs to be supported so that they do not disappear and become extinct over time. An increase in the attractiveness of dodol moyog is needed to add selling value to consumers by introducing the history, philosophy, and traditions of dodol moyog. With this increase, it is hoped that dodol moyog can become a gastronomic tourist attraction in Cirebon Regency.

The objectives of this research are as follows:

1) To know the philosophy, history, tradition, and social of dodol moyog snacks in Cirebon Regency;

2) To find out the standard recipe for making, raw materials, presentation methods, knowledge of nutrition, ethics and etiquette of dodol moyog snacks in Cirebon Regency;

3) To find out the efforts to develop traditional dodol moyog snacks in Cirebon Regency;

To find out the efforts of stakeholders in preserving the gastronomic tourism of traditional dodol moyog snacks in Cirebon Regency.

\section{Literature Review}

\subsection{Gastronomic Tourism}

Ningsih \& Turgarini (2020:267) revealed that gastronomic tourism is part of special interest tourism. Therefore, gastronomic tourism refers to trips made with the aim of enjoying food and drinks as the main factor in determining the 
decision to visit a tourist destination.

Nugroho \& Hardani (2020:54) revealed that it is different from other tourism products such as marine tourism, cultural and natural tourism which can be marketed as the main tourism product. Culinary tourism is usually marketed as a supporting tourism product in which one can learn the uniqueness that is served from a regional food. In addition, in gastronomic tourism, tourists are invited to take trips in which they enjoy food and drinks by understanding the process from the food or drink in a raw state, to cooking, to knowing the cultural values contained in each traditional food and drink of an area in order to get interesting knowledge tucked inside.

Turgarini (2018:19-20) stated that gastronomy is an art and science, even an appreciation across ethnicities, races, groups, religions, genders and cultures by studying food or drink in detail to get a culinary experience that is different from usual.

Taqwani (2012:55) said that gastronomy is a study of the relationship between a culture and a food and gastronomy studies various components of culture with food as its center related to culture. Gastronomy is born from different agricultural products in each region, so that it can produce different colors, tastes, and aromas from one food to another and can be traced to its origins as where the raw materials are produced.

Soeroso \& Susilo (2014:72) revealed that gastronomy is an element that unites new concepts in the form of cultural heritage and cultural tourism, which are driven by lifestyle habits and the need to have high quality experiences. Tourists increasingly want food and drinks that have cultural characteristics of an area, on the one hand, they can also preserve traditional specialty food and drinks of an area so as not to experience extinction.
Gastronomy itself presents a different way of serving and enjoying food or drink that makes it appear that there are unique things contained in a food or drink in a tourist destination, giving rise to a new experience for tourists who do it.

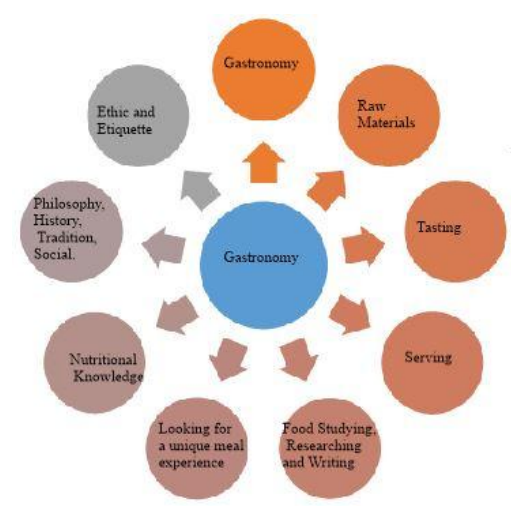

Figure 2. Gastronomic Components Source: Turgarini (2018:18)

According to Turgarini (2018:18) gastronomy does not only focus on how to enjoy a food or culinary, but includes choosing the raw materials, tasting, serving dishes, and consuming experiences as well as discovering, studying, researching and writing about food and everything related to human nutrition, philosophy, history, tradition, social, ethics and etiquette of a food consumed.

\subsection{Gastronomic Tour Packages}

Package tour as a summary of a tourist trip with one or more purpose of visit which is composed of several parts or at least two, in which there are various kinds of travel facilities in a fixed travel program, and sold according to prices involving all components of the tour. In addition, the existence of tour packages will facilitate a series of events for local and foreign tourists who visit. The whole series of itineraries is made so that tourists have their main travel motivation, namely to traditional travel, not just to consume the food Caliskan \& 
Yilmaz (2016:39).

The tour package subsystem according to Nuriata (2017:35) consists of:

1) Tourist is a person who travels to a tourist destination.

2) Tourist attraction is something that attracts tourists to make tourist visits in which they can impress.

3) Time is a series of when travel activities take place and in tour packages there is usually a predetermined time so that the tour takes place in an organized manner.

4) Tourist facilities refer to the facilities and infrastructure that are prepared for the smooth process of the tour that has been prepared by the tour package maker.

Gastronomic tourism is a tour that consists of the beginning of production, preparation, serving, consuming food and beverages and learning the ethics that are upheld in food both at the table and while cooking, participating in activities that have been arranged at tourist destinations such as visiting the location of food and beverages manufacturers then learn how the process of making them until it is they are ready to be served.

\subsection{Tourism Stakeholders}

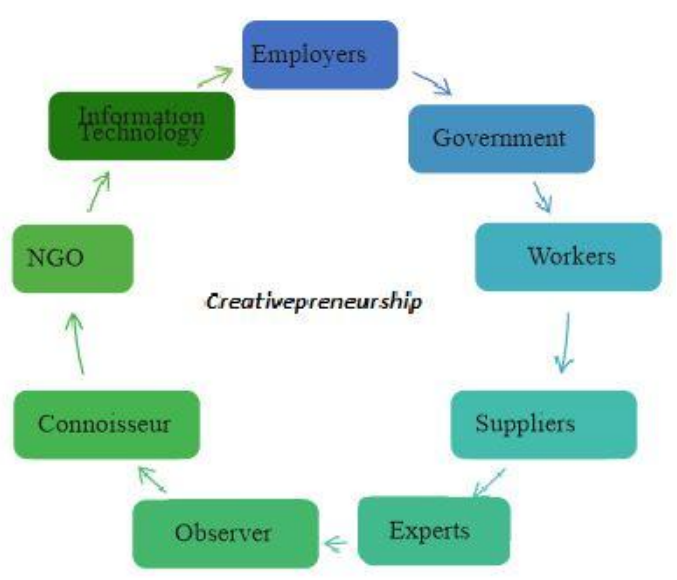

Figure 3. Stakeholders

Source: (Turgarini 2021:5)
Turgarini (2021:5) revealed that the development of a gastronomic city uses the Nona Helix or Salapan Cinyusu model by supporting creativity-based gastronomic entrepreneurship or creativepreneurship. This model is expected to help the contributors to be able to collaborate and participate in building the taste of Sundanese food so that they can go international.

It can be concluded that employers work together with their workers to develop a base for the food business, while the government or related agencies become facilitators in these activities. Experts, namely academics and practitioners, are involved to provide recommendations and ideas in creating innovations for businesses. Observers will contribute to providing constructive criticism, writing or reviews for continuous improvement of the resulting product.

Connoisseurs are owners of capital because they are pure consumers of gastronomy who are partners with entrepreneurs. Meanwhile, Non-Governmental Organizations can be the control, either at the input point at the point of origin of the farm, during the delivery or processing process into ready-to-eat food or at the end point at the dining table. Meanwhile, information technology functions as a promotional medium or a bridge between producers and consumers or even as an expert system to design various tools for supporting gastronomic businesses such as packaging.

\subsection{Tourism Development Gastronomy}

According to Turgarini (2018:4) that the development of gastronomic tourism is an accurate strategy for urban tourism development. Gastronomic tourism has a great contribution to the regional economy. 
Gastronomic tourism can create jobs and maintain local cultural heritage so as not to experience extinction, strengthen the sense of belonging to the local community. The development of gastronomic tourism will also make visiting tourists able to enjoy traditional specialty food and drinks that are served and display the manufacturing process, which means that it requires someone who is trained to demonstrate so that the visiting tourists can see directly and enjoy the demostration.

\section{Materials and Methods}

The research method used is qualitative research with a descriptive approach.

\subsection{Subject}

The subjects in this study are as follows:

Table 2. Subject

\begin{tabular}{|r|l|}
\hline \multicolumn{2}{|c|}{ Participants/ Source Persons } \\
\hline 1. & Dodol Moyog Producers \\
\hline 2. & Departement of Culture and Tourism \\
\hline 3. & Raw Materials Supplier \\
\hline 4. & Gastronomy Experts \\
\hline 5. & Observer \\
\hline 6. & Connoisseur \\
\hline 7. & Non Government Organization \\
\hline 8. & Information Media \\
\hline
\end{tabular}

Source: Data Processed by Researchers, 2021

Table 2. is a research subject who is then referred to as a participant or resource person who are expected to provide information and data related to the research being carried out.

\subsection{Location}

The research was conducted in Gegunung Village, Sumber District, Cirebon Regency. The area was chosen because there are dodol moyog sellers who still survive up to the present time.

\subsection{Data Collection Technique}

The data collection techniques used in this study were in-depth interviews, observation, literature studies, and documentation studies. The interview technique chosen is a structured interview, namely the list of questions asked has been planned and prepared beforehand so that the interview process can run in a structured manner.

\subsection{Data Analysis}

Research must pay attention to three things so that the research carried out gets scientifically accurate data, including data reduction, data presentation, drawing conclusions.

Data reduction is a form of analysis that directs, categorizes and organizes data so that final conclusions are obtained. Researchers conducted data reduction in order to gain an understanding of the data that had been collected from the results of interviews and field notes that had been carried out by summarizing and classifying according to the aspects of the problem being studied. After collecting data from various sources, the researcher grouped the data according to the answers from the informants.

Presentation of data is done by describing the data that has been collected in a narrative manner. The presentation of the data is arranged briefly, clearly and in detail in accordance with the aspects studied as a whole in addition to that so that it can be easier to understand.

At the conclusion stage, the researcher will conclude the data that the researcher has analyzed in the previous stage. The conclusions are in the form of a concise and clear arrangement, so it is hoped that in this way it will be more easily understood by the readers with reference to the purpose of the research itself. 


\section{Results and Discussion}

\subsection{Research Implementation}

The results of the research presented by the researcher are the results of interviews, observations and documentation, while the discussion is the result of research using a theoretical study point of view. The results of this study are interviews that have been conducted by researchers to informants from various different backgrounds. The following is a list of resource persons and the time of the interview conducted by the author starting from 07 June 2021 to 15 July 2021.

Table 3. List of Resource Persons and Interview Time

\begin{tabular}{|c|c|c|c|}
\hline No. & Day/Date & Name & Role \\
\hline 1. & $\begin{array}{c}\text { Monday, } 07 \\
\text { June } 2021\end{array}$ & Arimi & $\begin{array}{c}\text { Producer of } \\
\text { Dodol } \\
\text { Moyog }\end{array}$ \\
\hline 2. & $\begin{array}{c}\text { Monday, } 07 \\
\text { June } 2021\end{array}$ & Eni & $\begin{array}{c}\text { Producer of } \\
\text { Dodol } \\
\text { Moyog }\end{array}$ \\
\hline 3. & $\begin{array}{c}\text { Monday, } 07 \\
\text { June } 2021\end{array}$ & Saonah & $\begin{array}{c}\text { Producer of } \\
\text { Dodol } \\
\text { Moyog }\end{array}$ \\
\hline 4. & $\begin{array}{c}\text { Monday, } 07 \\
\text { June } 2021\end{array}$ & Fathan & $\begin{array}{l}\text { Connoisseur } \\
\text { of Dodol } \\
\text { Moyog }\end{array}$ \\
\hline 5. & $\begin{array}{c}\text { Monday, } 07 \\
\text { June } 2021\end{array}$ & Ipang & $\begin{array}{l}\text { Connoisseur } \\
\text { of Dodol } \\
\text { Moyog }\end{array}$ \\
\hline 6. & $\begin{array}{l}\text { Wednesday, } \\
\text { 16 June } \\
2021\end{array}$ & $\begin{array}{c}\text { Elang Iyan } \\
\text { Arifudin }\end{array}$ & $\begin{array}{l}\text { Culture } \\
\text { Observer }\end{array}$ \\
\hline 7. & $\begin{array}{l}\text { Wednesday, } \\
\text { 16 June } \\
2021\end{array}$ & Haryanto & Journalist \\
\hline 8. & $\begin{array}{l}\text { Thursday, } \\
17 \text { June } \\
2021\end{array}$ & $\begin{array}{l}\text { Nunung } \\
\text { Kurniasih }\end{array}$ & $\begin{array}{l}\text { Staff for } \\
\text { Culture }\end{array}$ \\
\hline 9. & $\begin{array}{c}\text { Monday, } 21 \\
\text { June } 2021\end{array}$ & $\begin{array}{c}\text { Mustaqiem } \\
\text { Asteja }\end{array}$ & $\begin{array}{l}\text { Cirebon } \\
\text { History } \\
\text { Observer }\end{array}$ \\
\hline 10. & $\begin{array}{c}\text { Monday, } 21 \\
\text { June } 2021\end{array}$ & Rina & $\begin{array}{c}\text { Dodol } \\
\text { Moyog Raw } \\
\text { Material } \\
\text { Seller }\end{array}$ \\
\hline 11. & $\begin{array}{c}\text { Tuesday, } 22 \\
\text { June } 2021\end{array}$ & $\begin{array}{l}\text { Ghina } \\
\text { Fauziyah }\end{array}$ & $\begin{array}{c}\text { Connoisseur } \\
\text { of Dodol } \\
\text { Moyog }\end{array}$ \\
\hline 12. & Tuesday, 22 & Rakhmat & Connoisseur \\
\hline
\end{tabular}

\begin{tabular}{|c|c|c|c|}
\hline No. & Day/Date & Name & Role \\
\hline & June 2021 & Alief & $\begin{array}{c}\text { of Dodol } \\
\text { Moyog }\end{array}$ \\
\hline 13. & $\begin{array}{l}\text { Thursday, } \\
\text { 24 June } \\
2021\end{array}$ & $\begin{array}{l}\text { Oktapiani } \\
\text { Pajriah }\end{array}$ & $\begin{array}{l}\text { Connoisseur } \\
\text { of Dodol } \\
\text { Moyog }\end{array}$ \\
\hline 14. & $\begin{array}{c}\text { Thursday, } \\
24 \text { June } \\
2021\end{array}$ & $\begin{array}{c}\text { Ghita Trie } \\
\text { Lestari }\end{array}$ & $\begin{array}{l}\text { Connoisseur } \\
\text { of Dodol } \\
\text { Moyog }\end{array}$ \\
\hline 15 . & $\begin{array}{l}\text { Thursday, } \\
\text { 24 June } \\
2021\end{array}$ & $\begin{array}{c}\text { Kapti } \\
\text { Lestari } \\
\text { Ningsih }\end{array}$ & $\begin{array}{l}\text { Connoisseur } \\
\text { of Dodol } \\
\text { Moyog }\end{array}$ \\
\hline 16. & $\begin{array}{l}\text { Monday, } 12 \\
\text { July } 2021\end{array}$ & $\begin{array}{c}\text { Riadi } \\
\text { Darwis }\end{array}$ & Gastronomist \\
\hline 17. & $\begin{array}{l}\text { Thursday, } \\
15 \text { July } \\
2021\end{array}$ & $\begin{array}{c}\text { Fikri } \\
\text { Umam }\end{array}$ & $\begin{array}{l}\text { Head of } \\
\text { GenPI } \\
\text { Cirebon }\end{array}$ \\
\hline
\end{tabular}

\subsection{Discussion}

The discussion here is a discussion of the results of research that has been carried out by researchers.

\subsubsection{Philosophy, History, Tradition and Social Snack Dodol Moyog}

1) Philosophy, History, Tradition, and Social Snack Dodol Moyog

The researchers discover that no one knows for sure what the history of the early dodol moyog snack was like. However, the sweet-tasting food are thought to have developed since the 15 th century. In addition, the possibility of the emergence of dodol moyog originated from the transfer of raw materials or utilizing available raw materials through community creativity which aims to make dishes that are not only delicious but also have the advantage of being more durable and having a selling value.

As for another possibility that this dodol moyog snack is made from aci flour or tapioca flour, it is an assimilation from the Chinese and Cirebon, considering that Cirebon is a mixing place for cultures from Sundanese, Javanese, Chinese and even Arab culture elements. The dodol moyog snack made from white tapioca flour illustrates the cleanliness of the heart. 
The naming of moyog comes from the manufacturing technique, namely in "oyog-oyog" or stirred until it becomes lunkhead, while the texture of this dodol moyog is chewy because it is made of tapioca flour so that the texture is oyag or swaying so that the name moyog is based on the texture and manufacturing technique.

Based on other sources, the name moyog comes from the way it is made which is very tiring because moyog comes from the Cirebon dialect which means tired or tired. Dodol moyog has a topping called "mata ula", the name mata ula comes from its shape which is considered to be like a snake's eye.

From the technique of making dodol moyog there is no specific philosophy, but from the literature study that has been done by researchers, how to make and serve dodol moyog has similarities to bubur lolos.

Bubur lolos is a kind of porridge which is usually served at seven-monthly events for pregnant women for the Sundanese people, the naming is not without reason, this porridge is considered as a symbol so that the process of giving birth going smoothly or lolos.

Bubur lolos is made from rice flour, glutinous rice flour and tapioca flour mixed together with palm sugar and coconut milk to form a chewy dough. The coconut milk used to make bubur lolos is should be thick coconut milk so that when it is cooked it releases oil which makes it the porridge not sticky when wrapped. In addition, bubur lolos has a blondo topping. Blondo is thick coconut milk which is cooked until it almost forms oil. This porridge is wrapped in a banana leaf which is not covered on one side (food.detik.com).

Dodol moyog is a dodol from Cirebon which is characterized by a marble motif in each piece and has a mata ula or blondo topping. This snack has a sweet taste combined with savory from the mata ula. The texture and shape of the typical dodol moyog is still the same from ancient times until now because it is passed down from generation to generation and maintains its original shape.

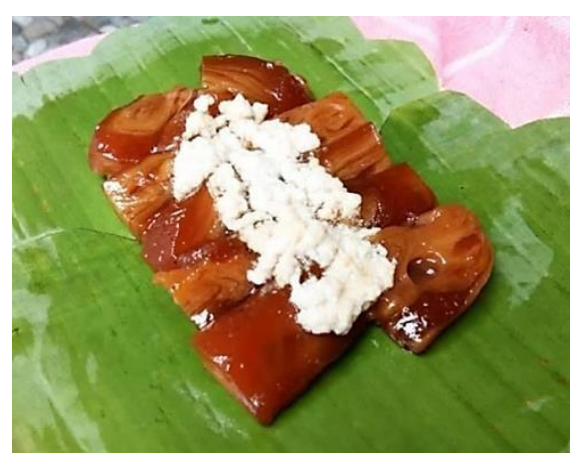

Figure 4. Dodol Moyog

Source: Personal Documentation, 2021

There are no myths found in the dodol moyog snack. In the past, it was often found at community events because in ancient times the people were high in mutual cooperation, besides that dodol moyog was made in large quantities such as wedding celebrations, circumcisions, thanksgiving or village traditional events such as sedekah bumi, parikan, mapag sri and munjung buyut.

\section{Looking for a Unique Dining Experience}

The uniqueness of dodol moyog lies in the material used because in general the material used to make dodol is using glutinous rice flour while dodol moyog uses the most refined tapioca flour. In addition, the uniqueness of dodol moyog that is not owned by dodol in general is the presence of mata ula or blondo topping made of thick coconut milk which is cooked for a long time to almost form oil. Mata ula or blondo is what makes the taste of dodol moyog not only sweet but also has a savory taste.

Dodol moyog has a fairly long manufacturing process because it cooks 
in large quantities for approximately three hours and the process of making mata ula is quite long, which is approximately one to two hours. The manufacturing process also requires a wood-fired stove because it is considered to have the right flame. Making dodol moyog itself requires special skills because the dodol moyog dough must be stirred until the dough really thickens and nothing burns until the final stage, so it requires considerable energy when making it and cannot be left alone.

Dodol moyog has similarities with bubur lolos in terms of shape and presentation of the toppings. However, the bubur lolos uses glutinous rice flour as the raw material, while the dodol moyog uses tapioca flour and the identical dodol moyog calls blondo as mata ula.

\subsubsection{Standard Recipe of Raw} Material-Making, Tasting, Serving, Ethics and Etiquette Attached to Dodol Moyog Snack

\section{1) Raw Material}

The ingredients for making dodol moyog are tapioca flour, palm sugar, salt and water. The following is the measurement of the raw materials used to make dodol moyog:
a. Tapioca flour SPM $6,5 \mathrm{~kg}$,
b. Palm sugar $3,5 \mathrm{~kg}$,
c. Salt 125 gr,
d. Water 8 lt.

The raw materials used to make dodol moyog must be of good quality, then for the tapioca flour used to make dodol moyog it must be the smoothest tapioca flour because if you use ordinary tapioca flour it will not turn out or the results will be not good and dodol moyog manufacturers suggest to using the SPM brand. The sugar used must be palm sugar because it has a delicious taste and distinctive fragrance.

All the raw materials used to make dodol moyog are obtained directly from Jagasatru Market, Cirebon City. There is no special supplier for the raw materials for making dodol moyog, all materials are obtained from the direct market. Manufacturers also do not store raw materials, so for the daily sales of dodol moyog producers shop on the same day.

Tools commonly used to make dodol moyog are as follows:

a. A large wok is used to make dodol moyog, the large size was chosen because it is used to make dodol moyog in large quantities.

b. A wooden spatula is used to stir the ingredients and the dodol moyog dough until it thickens. The wooden spatula was chosen because it is more natural and stronger for stirring tools than an iron spatula.

c. The furnace is used for the dodol moyog cooking process.

d. Firewood is used for the process of cooking dodol moyog, firewood is used so that the fire used can be stable and does not eliminate the traditional characteristics of cooking dodol moyog. Cooking using firewood will produce a more delicious taste of dodol moyog than using a gas stove.

e. The food mat is used as a base to flatten and cool the cooked dodol moyog.

2) Culinary Arts/Cooking

The way to make dodol moyog snacks is as follows:

a. Prepare a wood-burning stove until the fire is on. First prepare to make the mata ula. Prepare thick coconut milk then mix it with sugar and salt to taste so that the mata ula has a savory taste. Cook the thick coconut milk for about one to two hours until 
it almost forms oil. When finished, set aside to cool.

b. Second, prepare to make dodol moyog. Prepare a pan on the stove, put water in the pan, add palm sugar then stir, boil until the palm sugar melts. After melting, lower the pan from the top of the stove. Set aside.

c. Prepare a large wok on the stove, then add the melted palm sugar into the wok little by little while filtering so that if there is any dirt it can be picked up. Do this until the liquid sugar in the pan runs out.

d. After that add salt.

e. Prepare another clean container, add water then add tapioca flour, stir first in the container so that the tapioca flour and water blend well and there are no lumps.

f. Put the tapioca flour mixture that has been prepared earlier into the wok that already contains liquid palm sugar, add tapioca flour little by little while filtering.

g. After all the ingredients are put into the pan, stir continuously for about three hours until the dodol moyog mixture thickens.

h. After the dodol moyog is cooked and thickens. Set aside for a moment.

i. Prepare a clean base and coat it with coconut oil so it doesn't stick.

j. The cooked dodol moyog was placed on a mat that had been coated with coconut oil, smoothed out.

k. After flattening, let stand until dodol moyog cool.

1. Then the cold dodol moyog is cut into pieces and topped with mata ula. Once done, it is ready to be packaged.

\section{3) Serving}

There are differences in the presentation to customers in the past and now. In the past, dodol moyog was served using banana leaves and given a "lidi" like "dipepes", the taste was even more delicious and the aroma was more fragrant.

However, along with the times, now dodol moyog is served using plastic and then stamped so that it can be closed. This method is considered practical and is done so that the mata ula is visible and dodol moyog look more beautiful.

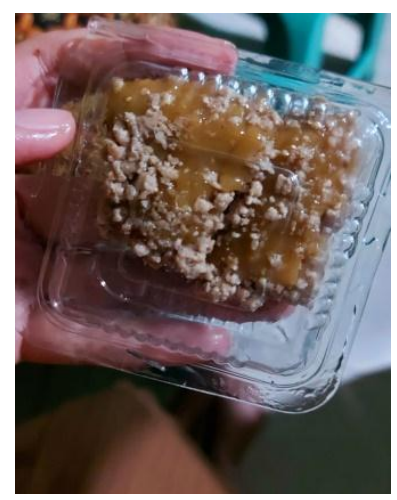

Figure 5. Presentation of Dodol Moyog Using Plastic

Dodol moyog only lasts for five days. If the dodol moyog has passed five days or the expiration date the color and aroma change, then the dodol moyog can no longer be consumed and there is no other way to maintain the quality of the dodol moyog.

\section{4) Tasting}

There is no difference in taste, aroma and appearance of dodol moyog then and now. But what makes the difference is the way of packaging or presentation to consumers. So far, producers who are still producing dodol moyog are trying to maintain the original taste of dodol moyog, which is sweet from palm sugar and savory from mata ula.

Dodol moyog is suitable for consumption for friends when relaxing combined with warm plain tea or warm water because dodol moyog already has a sweet and savory taste. According to dodol moyog producers, to get the taste 
of dodol moyog, it is enough to consume one pac, but there is no limit to consuming dodol moyog depending on who consumes it.

\section{5) Ethics and Etiquette}

There are no special rules for people who want or are eating dodol moyog. However, because the majority of the people of Cirebon are Muslim, proper eating etiquette according to religious teachings is to wash your hands first, then read a prayer before eating and not eat while standing.

The dodol moyog maker must be in a clean and tidy condition, this regulation applies to work in all fields, especially in the culinary field. The HACCP (Hazard Analysis and Critical Control Point) standard that is applied now has been applied by parents since ancient times. If it is related to the habits of the kitchen workers in the palace, people who want to cook must be clean and tidy, the health of those who want to cook also needs to be considered, then when cooking should present a clean heart, read more dhikr and prayer during cooking because it will affect the taste of food made, because when multiplying dhikr and prayer, it can be ascertained that the cook is in a state of focus.

6) Food Studying, Researching and Writing

There has been no previous research on dodol moyog and there is no written data or documentation about dodol moyog.

\section{7) Nutritional Knowledge}

The benefits of dodol moyog for the body is to provide energy because in dodol moyog there are carbohydrates and palm sugar which are useful for increasing energy in the human body. The following is a manual calculation of the nutritional content in one serving of dodol moyog:

Table 4. Dodol Moyog Nutritional Content

\begin{tabular}{|l|r|}
\hline \multicolumn{2}{|c|}{ Dodol Moyog } \\
\hline Energy & $117 \mathrm{kkal}$ \\
\hline Protein & $1,18 \mathrm{gr}$ \\
\hline Fat & $1,8 \mathrm{gr}$ \\
\hline Carbohydrate & $24,43 \mathrm{gr}$ \\
\hline Fiber & $1 \mathrm{gr}$ \\
\hline Sugar & $13,08 \mathrm{gr}$ \\
\hline Potassium & $29,33 \mathrm{mg}$ \\
\hline Phosphor & $20 \mathrm{mg}$ \\
\hline Iron & $2 \mathrm{mg}$ \\
\hline
\end{tabular}

Source: Data Processed by Researchers, 2021

In one serving or 30 grams of dodol moyog contained a fairly high energy, namely $117 \mathrm{kcal}$. Because dodol moyog is made from tapioca flour, the content of dodol moyog is dominated by carbohydrates. Carbohydrates are needed by the human body as the main energy source. In addition, energy is needed by the human body to breathe and to carry out daily activities.

\subsubsection{Development Effort of Gastronomy}

1) Taste and Scent

Dodol moyog manufacturers really maintain the original quality of taste and aroma in dodol moyog, therefore manufacturers use quality ingredients. Efforts to develop in terms of taste can be done by adding flavor variants to the dodol moyog so that it is not boring.

2) Variation

Attractive packaging will be more attractive to consumers and increase the selling value of dodol moyog. 


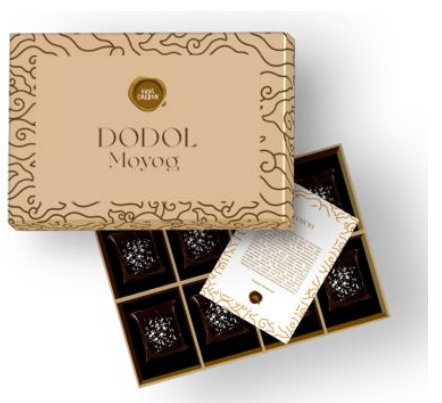

Figure 6. Kraft Carton Packaging

The following is the recommended packaging for dodol moyog manufacturers, the packaging is made of kraft carton with a size of $24 \mathrm{~cm} \times 8 \mathrm{~cm} \times 12 \mathrm{~cm}$. The kraft carton and clear wrapping materials for dodol moyog were chosen because dodol moyog is a food that is heavily coated with coconut oil, so using the thick packaging is considered safer and more practical for long trips. In addition, packaging made of kraft cardboard has the advantage of being environmentally friendly and recyclable.

\section{3) Sanitation and Hygiene}

The application of hygiene and sanitation is very necessary as an added value for producers, besides that cleanliness at the production site will affect the quality of the products. The application of sanitation and hygiene at the production site can also prevent pollution that can lead to undesirable things such as food poisoning.

\subsubsection{Stakeholder Efforts to Preserve the Dodol Moyog}

\section{1) Employers and Workers}

The marketing target of dodol moyog is for all people, because all people can try dodol moyog snacks. In addition, the marketing process is carried out at the production site and in the market by word of mouth only. The producer said that he had never participated in any business training conducted by any party. Producers hope to get more support from various parties besides business development, so that dodol moyog is better known by the people of Cirebon and outside Cirebon.

\section{2) Government}

Efforts that have been made by the government in preserving gastronomy in Cirebon Regency in general are by doing a lot of documentation about gastronomy in Cirebon Regency so as not to experience extinction. Incorporating traditional food materials into subjects in schools related to skills. Conducting a gastronomic street food festival in the BAT Cirebon area by serving many traditional food stands.

According to sources, dodol moyog has a high potential to be used as a tourist attraction because of its uniqueness. However, there are several things that must be improved so that dodol moyog can be used as a tourist attraction, such as improving packaging that is more attractive and contemporary so that consumers are more interested in buying traditional food, improving hygiene, sanitation in production sites and increasing promotion to the public at large by promoting it through social media.

\section{3) Experts and Observers}

Efforts that can be made to keep the traditional food of dodol moyog from experiencing extinction is to create ways so that people can love the food. Then cooperation between stakeholders, making written documentation so that it is not lost. In terms of preserving it is very much needed because dodol moyog is very likely to be used as a gastronomic tourist attraction. Many efforts can be made to preserve dodol moyog and other traditional foods such as the Decree of the Regent or the Governor regarding the regulations for serving traditional regional food in every meeting agenda, then in the school canteens serving traditional regional food, making traditional regional food festivals, by including traditional food in events in 
the community, it is hoped that traditional food will be more widely known by the community.

Things that must be improved to make dodol moyog as a tourist attraction is to always pay attention to artistic packaging, hygiene and promotion. By doing promotions, it will be easier to be known by the wider community, especially in this digitalization era, it should be utilized by raising traditional cuisines that many people do not know so that they do not become extinct.

\section{4) Supplier}

Dodol moyog manufacturers do not have a special supplier, because dodol moyog producers move around in shopping for raw materials. However, there is one producer, namely Mrs. Rina, a seller of tapioca flour and palm sugar. According to Mrs. Rina, there are no definite obstacles dodol as a moyog producer so far.

\section{5) Connoisseur}

The first impression that is felt when enjoying dodol moyog is the sweet and savory taste that is obtained from the mata ula. According to sources, most people like dodol moyog because it tastes delicious and the sweet taste doesn't make you feel bad. However, there are things that must be improved from dodol moyog, namely the packaging and promotion.

In addition to the delicious taste, dodol moyog has an affordable price and it is hoped that dodol moyog can remain sustainable and exist so that it is easier to find sellers of dodol moyog and make it better known to the wider community.

\section{6) NGO (Non Government Organization)}

Efforts have been made by Generasi Pesona Indonesia Cirebon (GenPI Cirebon) towards the ypical specialty food of dodol moyog, namely by trying the food and utilizing social media and publishing through the GenPI Cirebon Instagram account, namely @genpicirebon which aims to make the public see the promotion so that they know the specialty traditional food of Cirebon Regency which is rarely found.

According to sources, dodol moyog has a great opportunity as a gastronomic tourist attraction from Cirebon Regency because the food is rarely found. Things that must be improved so that dodol moyog remains sustainable and can become a gastronomic tourist attraction is by improving the presentation concept by combining traditional concepts with modern concepts and then increasing promotions.

\section{Information Technology}

One of the efforts that have been made by the information media is to share information about dodol moyog through Radar Cirebon Televisi with the Icip Uyup program. Icip Uyup comes from the name "Icip" which means more related to food and "Uyup" more to the drink. At first this program was made more to introduce traditional Cirebon regional specialties but over time, Icip Uyup also introduced modern foods and helped introduce new culinary businesses such as cafes and restaurants but continued to help introduce street food.

\subsubsection{Tour Packages}

Researchers designed a dodol moyog gastronomic tour package that aims to give a different and unique impression and dining experience to visiting tourists. The target for this dodol moyog gastronomic tour package is tourists from within the city, outside the city and foreign tourists who are really interested in traditional food from Cirebon Regency which is rarely found. In addition, students can also be targeted because it is an educational material and also introduces traditional food so as to increase knowledge to the younger generation about traditional foods typical of the Cirebon Regency which must be preserved. 
In the tour package, the making of dodol moyog will be adjusted to the number of participants, namely four people. Then the dough that will be made is $1 \mathrm{~kg}$ or it will be 32 pcs of dodol moyog. In this tour package, each participant will bring home a box which contains 8 pcs of dodol moyog.

Table 5. Dodol Moyog Gastronomic Tour Plan

\begin{tabular}{|c|c|c|c|c|}
\hline Time & Duration & Activity & Description & Location \\
\hline $08.00-08.05$ & 5 & $\begin{array}{l}\text { Participants } \\
\text { arrived at the } \\
\text { parking lot close } \\
\text { to the dodol } \\
\text { moyog production } \\
\text { site. }\end{array}$ & $\begin{array}{l}\text { Vehicles are parked } \\
\text { then participants walk } \\
\text { to the production site }\end{array}$ & $\begin{array}{l}\text { Parking lot in } \\
\text { Gegunung } \\
\text { Village, Sumber } \\
\text { District, } \\
\text { Cirebon } \\
\text { Regency. }\end{array}$ \\
\hline 08.05-08.35 & $30^{\prime}$ & $\begin{array}{l}\text { Introduction and } \\
\text { explanation } \\
\text { session about } \\
\text { dodol moyog } \\
\text { food. }\end{array}$ & $\begin{array}{l}\text { Participants will be } \\
\text { given an explanation } \\
\text { of the philosophy and } \\
\text { also the equipment } \\
\text { used to make dodol } \\
\text { moyog. }\end{array}$ & $\begin{array}{l}\text { Place for dodol } \\
\text { moyog } \\
\text { producers. }\end{array}$ \\
\hline 08.35-09.35 & $60^{\prime}$ & $\begin{array}{l}\text { The process of } \\
\text { making mata ula. }\end{array}$ & $\begin{array}{l}\text { Participants will be } \\
\text { explained given an } \\
\text { explanation on how to } \\
\text { make mata ula eyes } \\
\text { for dodol moyog } \\
\text { topping. }\end{array}$ & $\begin{array}{l}\text { Place for dodol } \\
\text { moyog } \\
\text { producers. }\end{array}$ \\
\hline 09.35-11.05 & 90 & $\begin{array}{l}\text { The process of } \\
\text { making dodol } \\
\text { moyog. }\end{array}$ & $\begin{array}{l}\text { Participants will be } \\
\text { explained given an } \\
\text { explanation on how to } \\
\text { make dodol moyog } \\
\text { and are welcome to } \\
\text { try to cook dodol } \\
\text { moyog in turn. }\end{array}$ & $\begin{array}{l}\text { Place for dodol } \\
\text { moyog } \\
\text { producers. }\end{array}$ \\
\hline $11.05-12.35$ & 30 & $\begin{array}{l}\text { Cooling the dodol } \\
\text { moyog and } \\
\text { cutting the dodol } \\
\text { moyog. }\end{array}$ & $\begin{array}{l}\text { Participants are } \\
\text { welcome to try cutting } \\
\text { and tasting dodol } \\
\text { moyog. }\end{array}$ & $\begin{array}{l}\text { Place for dodol } \\
\text { moyog } \\
\text { producers. }\end{array}$ \\
\hline $12.35-12.40$ & 5 & Photo session & $\begin{array}{l}\text { Participants take } \\
\text { photos with producers } \\
\text { while carrying dodol } \\
\text { moyog products } \\
\text { as a souvenir. }\end{array}$ & $\begin{array}{l}\text { Place for dodol } \\
\text { moyog } \\
\text { producers. }\end{array}$ \\
\hline 12.40-- & & Go Home & $\begin{array}{l}\text { Participants are } \\
\text { allowed to go home. }\end{array}$ & Parking lot \\
\hline
\end{tabular}


Table 5. above describes the time, duration, activities that can be carried out at the dodol moyog production site, as well as information that explains the details of these activities. Dodol moyog gastronomic tour activities can be carried out at the dodol moyog producer located in Block 1 RT 02 RW 01 Gegunung Village, Sumber District, Cirebon Regency.

One visit to the dodol moyog gastronomic tour can accommodate as many as four participants at a cost of $\mathrm{Rp}$. 250,000. At a cost of Rp. 250,000, participants have received facilities in the form of a welcome drink, an explanation of the gastronomic components of dodol moyog, learning and practicing how to make dodol moyog, tasting dodol moyog, and bringing home four boxes of dodol moyog. Moyog.

Gastronomy Travel Brochure for Dodol

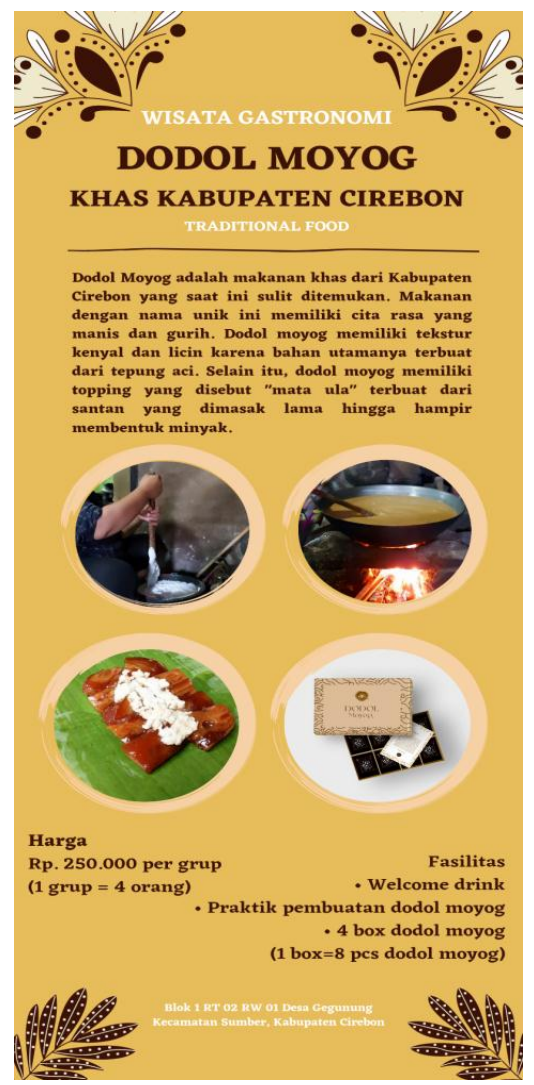

Figure 7. Gastronomy Travel Brochure for Dodol Moyog

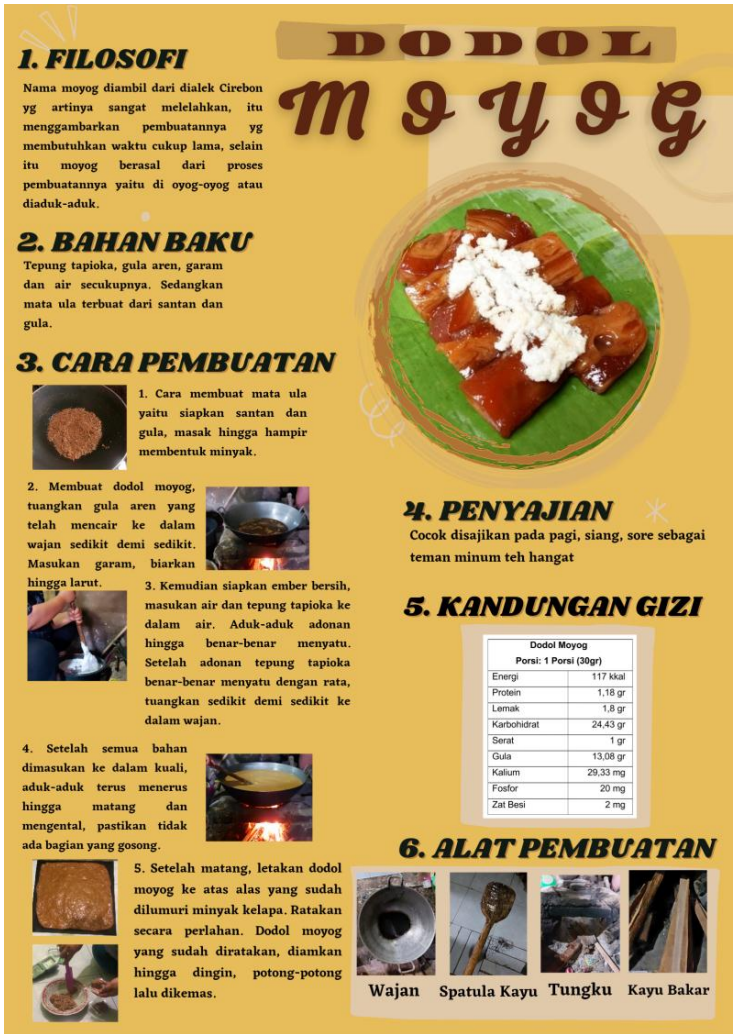

Figure 8. Infographics of Dodol Moyog

Source: Personal Documentation, 2021

\section{Conclusions}

Based on the findings and previous discussions regarding the Preservation of Dodol Moyog as a Gastronomic Tourist Attraction in Cirebon Regency, it can be concluded as follows:

1) Dodol moyog is a traditional snack specialty of Cirebon Regency which is currently starting to become rare. No one knows for sure how the history of dodol moyog is, it is possible that dodol moyog was created because of the creativity of the Cirebon people in utilizing available raw materials so that dodol moyog is a snack that is not only delicious but also has added value, which is more durable. In addition, dodol moyog is a sweet snack, it is estimated that the sweet snack developed in the 15th century. Dodol moyog has a unique name. The name moyog comes from the Cirebon dialect which means tired or very tiring, it describes the way it is made 
which takes a long time from liquid dough to become thick dodol moyog dough. In addition, "oyog-oyog" has the meaning of being stirred according to the way it is made, namely by stirring until it thickens. Another uniqueness possessed by dodol moyog is that there is a marble motif in each layer of the cut and has mata ula or blondo topping. It was named mata ula because its shape is considered similar to a snake's eye. Mata ula or blondo is made from thick coconut milk that is cooked for a long time until it almost forms oil. From the beginning of the creation of dodol moyog the shape is still the same and there is no change. In the process of making dodol moyog, patience is needed because it takes a long time and the strength of energy to stir continuously until it is cooked.

2) The raw materials used to make dodol moyog are fine tapioca flour SPM, palm sugar, salt and enough water. Meanwhile, to make the mata ula topping, use coconut milk and add enough sugar. The manufacturing process is still traditional such as wok, wood stirrer and firewood. Dodol moyog is served to consumers using mica plastic, this presentation is considered practical to be given to consumers. There is no difference in taste, aroma and color in dodol moyog from time to time, until now the taste of dodol moyog is sweet and savory which is obtained from the mata ula. The texture of dodol moyog is chewy and slippery because it is made from SPM fine tapioca flour. Dodol moyog is usually eaten with warm plain tea or water because dodol moyog already has a sweet taste. Dodol moyog can be eaten anytime as a snack to relax with family,

3) The manufacturer of dodol moyog said that they had varied the taste of the dodol moyog snack, but because the making of dodol moyog took a long time, the making of other flavor variants on the dodol moyog did not last long due to limited energy and everything was still done by themselves. In addition, based on a suggestion from one of the consumers of dodol moyog, it should be kept with the original taste because consumers are more dominated by the original taste of dodol moyog,

4) Cooperation between stakeholders is very much needed in preserving the traditional food of Cirebon Regency. The government is involved regularly in promoting festivals related to traditional food as an effort to preserve and promote tourism, culture and gastronomy in Cirebon Regency. In addition, the government also conducts various trainings and business development for culinary entrepreneurs. Meanwhile, the efforts made by the community and information media in Cirebon Regency are by creating programs that can introduce and promote gastronomy in Cirebon Regency. Icip Uyup is a program created by Radar Cirebon Televisi in order to introduce Cirebon gastronomy and help promote culinary businesses that are developing.

\section{Sugestion}

Based on the research, the researcher suggests several things related to dodol moyog so that this traditional snack specialty of Cirebon Regency is preserved, namely as follows.

1) Expanding the marketing of dodol moyog so that dodol moyog is better known by the public by promoting it through social media, such as creating a special Instagram account. Participating in food festivals held by local governments or from other parties in order to expand the 
marketing network and promotion of dodol moyog.

2) Producers are expected to develop products better in terms of taste, aroma and shape so that they are more attractive to consumers.

3) Replacing the packaging with a better and safer one but not forgetting the artistic and environmentally friendly impression, so that it is expected to attract consumers' interest.

4) Continue to make dodol moyog as a snack that is present at events in the community such as celebrations and village traditional ceremonies.

5) It is hoped that the dodol moyog producers can pay attention to the rules for better hygiene and sanitation and follow various business developments carried out by the local government and other parties.

6) It is hoped that the local government can pay more attention to small business actors of traditional foods so that their existence does not become extinct and can be managed properly so that they are able to compete with modern foods that are developing in the community.

7) With the results of this research, it is hoped that it will be useful and become the basis for the development of gastronomic tourism for traditional snacks in Cirebon Regency.

\section{Acknowledgment}

The author would like to thank Mrs. Dr. Dewi Turgarini, SS., MM.Par as a lecturer who guides the author in completing this journal. Mr. Dr. Riadi Darwis, M.Pd who has patiently guided the author in completing the journal as well as being a resource person in this research. Arimi, Eni, Iyan, Nunung, Mustaqim, Haryanto, Fikri, Rina and Saonah, who have been willing to be resource persons and have taken the time to provide information to the authors both directly and online.

\section{References}

Basrowi dan Suwandi. (2008). Memahami Penelitian Kualitatif. Jakarta: Rineka Cipta.

Caliskan, O., \& Yilmaz, G. (2016). Gastronomy and Tourism. In Global Issue and Trend in Tourism (pp. 33-50). Sofia: St. Kliment Ohridski University Press.

Emzir. (2014). Metodologi Penelitian Kualitatif: Analisis Data. Rajawali Press.

Firmani, S. N., Turgarini, D., \& Putra, M. K. (2018). Pelestarian Kudapan Kalua Kulit Jeruk sebagai Warisan Gastronomi Sunda di Ciwidey Jawa Barat. Gastronomy Tourism Journal, 5(1), 35-51

Moleong, J. L. (2009). Metodologi Penelitian Kualitatif. Remadja Karya.

Ningsih, C., \& Turgarini, D. (2020). Preservation And Development of Kampung Nikmat as Tourist Destination for Sunda Gastronomy Cultural Heritage. Tourism Scientific Journal, Vol 5 (juni 2020)

Nugroho, S. P., \& Hardani, I. P. (2020). Gastronomi Makanan Khas Keraton Yogyakarta sebagai Upaya Pengembangan Wisata Kuliner. Jurnal Pariwisata, 7(April 2020).

https://ejournal.bsi.ac.id/ejurnal/in dex.php/jp

Nuriata, S. E. (2017). Paket Wisata Penyusunan Produk dan Penghitungan Harga. Alfabeta.

Pratiwi, Y. (2020). Traditional Fish Gangan : An Icon of Gastronomic Tourism from Belitung Island. Gastronomy Tourism Journal, 7(December), 14-19.

Soeroso, A., \& Soesilo, YS. (2014). 
Traditional Indonesian

Gastronomy as a Cultural Tourism

Atrraction. Journal of Applied

Economics in Developing

Countries, $1, \quad 45-49$. http://uns.ac.id

Turgarini, Dewi. (2018). Gastronomi

Sunda Sebagai Daya Tarik Wisata

Kota Bandung. Universitas Gadjah

Mada, Yogyakarta.

Turgarini, Dewi. (2021). The Salapan
Cinyusu (Nona Helix) as A "Creativepreneurship" Support Model for Gastronomy Tourism in Bandung City. Promoting Creative Tourism: Current Issues in Tourism Research, 429-437. doi: https://doi.org/10.1201/9781003095 484-62 
